\title{
Effect of feeding distillers grains during different phases of production and addition of postmortem antioxidants on shelf life of ground beef ${ }^{1}$
}

\author{
B. D. Cleveland, J. O. Buntyn, A. L. Gronli, J. C. MacDonald, PAS, and G. A. Sullivan² \\ Department of Animal Science, University of Nebraska, Lincoln 68583-0908
}

\section{ABSTRACT}

Feeding distillers grains (DGS) to cattle can increase PUFA concentration, increase lipid oxidation, and decrease color stability of beef. The objective of this study was to evaluate the effects of feeding DGS and the postmortem addition of antioxidants on the shelf life of ground beef products. Crossbred heifers $(\mathrm{n}=64$; initial $\mathrm{BW}=225$ $\mathrm{kg}$ ) were supplemented with different amounts of modified DGS (MDGS; 0.91 or $2.27 \mathrm{~kg}$ daily, DM basis) during backgrounding and finished on diets containing corn gluten feed or MDGS. Four beef shoulder clods from each dietary group were ground independently. Fatty acid composition was analyzed in lean tissue, s.c. fat, and composite samples. Raw patties in retail display were analyzed for lipid oxidation, percent discoloration, and objective color. Cooked beef links were manufactured with salt, phosphate, and varying quantities of an antioxidant (rosemary and green tea extract), and lipid oxidation was measured throughout storage. Finishing cattle fed MDGS had greater C18:2 and PUFA $(P \leq 0.028)$ content in all locations, whereas cattle supplemented with greater amounts of MDGS during backgrounding had more C18:0 $(P=$ $0.005)$ and less $\mathrm{C} 16: 1(P=0.020)$ in s.c. fat. Raw ground beef from heifers finished with MDGS discolored at a greater rate $(P<0.001)$, but lipid oxidation was not different $(P=0.47)$. Greater lipid oxidation in cooked beef links occurred when cattle were fed greater amounts of MDGS during backgrounding or MDGS during finishing, but adding the rosemary and green tea extract decreased lipid oxidation regardless of dietary treatment.

Key words: distillers grains, fatty acid composition, ground beef, lipid oxidation, rosemary and green tea extract

\footnotetext{
The authors declare no conflict of interest.

${ }^{1}$ A contribution of the University of Nebraska Agriculture Research Division supported in part by funds provided through the Hatch Act and from the Beef Checkoff.

${ }^{2}$ Corresponding author: gary.sullivan@unl.edu
}

\section{INTRODUCTION}

In 2013, 35.5 million metric tons of distillers grains (DGS) was produced as coproducts of the fuel ethanol industry, and beef cattle account for almost half of DGS consumption (Renewable Fuel Association, 2016). Researchers have reported that steaks from cattle fed wet DGS (WDGS) have a greater PUFA concentration and less oxidative stability (Jenschke et al., 2008; Depenbusch et al., 2009) and that feeding WDGS can increase lipid oxidation in ground beef (Koger et al., 2010) compared with beef from cattle not fed DGS.

Lipid oxidation occurs most readily in PUFA and is associated with rancidity or warmed-over flavors in beef. The free radicals formed from lipid oxidation can increase myoglobin oxidation (Liu et al., 1995), and likewise, myoglobin oxidation can promote lipid oxidation (Faustman et al., 2010). Comminuting meat increases lipid oxidation by disrupting the phospholipid membranes and allowing for greater exposure to oxygen (Sato and Hegarty, 1971). Cooking meat increases lipid oxidation by the release of free- and heme-iron from myoglobin (Greene and Cumuze, 1982). Much research has been conducted on feeding DGS in finishing diets to cattle on raw steak and ground beef characteristics (Jenschke et al., 2008; Depenbusch et al., 2009; Koger et al., 2010); however, few have investigated the effect of supplementation with DGS during backgrounding (Buttrey et al., 2012). Dierks et al. (2017) reported that supplementation of dried DGS (DDGS) during backgrounding resulted in greater lipid oxidation of cooked beef patties than nonsupplemented cattle. Dierks et al. (2017) also reported an unexpected reduction in lipid oxidation in cooked beef patties from cattle finished with WDGS than when no WDGS was fed. They suggested the inclusion of different fat depots and the cooking process of cooked ground beef links were possible explanations.

The use of plant extracts such as rosemary or green tea as natural antioxidants is common in meat processing. Both rosemary and green tea have phenolic compounds that donate the phenolic hydrogen to quench free radicals formed during lipid oxidation (Tang et al., 2001). 
Table 1. Finishing diet composition (\% of diet DM basis)

\begin{tabular}{|c|c|c|}
\hline Item, \% & CCGF & MDGS \\
\hline High-moisture corn & 50.0 & 50.0 \\
\hline $\mathrm{CCGF}^{1}$ & 40.0 & - \\
\hline MDGS $^{2}$ & - & 40.0 \\
\hline Wheat straw & 5.0 & 5.0 \\
\hline Supplement & 5.0 & 5.0 \\
\hline \multicolumn{3}{|c|}{ Supplement composition, \% of diet DM } \\
\hline Fine-ground corn & 2.7650 & 2.7650 \\
\hline Limestone & 1.7150 & 1.7150 \\
\hline Salt & 0.3000 & 0.3000 \\
\hline Tallow & 0.1300 & 0.1300 \\
\hline Beef trace mineral ${ }^{3}$ & 0.0500 & 0.0500 \\
\hline Rumensin- $90^{4}$ & 0.0167 & 0.0167 \\
\hline Tylan- $40^{5}$ & 0.0083 & 0.0083 \\
\hline Vitamin A-D-E 6 & 0.0150 & 0.0150 \\
\hline \multicolumn{3}{|c|}{ Analyzed nutrient composition, \% DM basis } \\
\hline $\mathrm{CP}$ & 15.0 & 18.4 \\
\hline Fat & 4.25 & 7.01 \\
\hline NDF & 19.7 & 23.3 \\
\hline
\end{tabular}

${ }^{1}$ CCGF = commercial corn gluten feed (Sweet Bran, Cargill Corn Milling, Blair, NE); contained $4.49 \%$ fat; fatty acid composition: $\mathrm{C} 16: 0=21.18 \%, \mathrm{C} 18: 0=3.99 \%, \mathrm{C} 18: 1=25.91 \%, \mathrm{C} 18: 2=$ $46.24 \%$, C18:3 $=2.69 \%$.

${ }^{2}$ MDGS = modified distillers grains with solubles; contained $11.39 \%$ fat; fatty acid composition: $\mathrm{C} 16: 0=14.92 \%, \mathrm{C} 18: 0=2.12 \%, \mathrm{C} 18: 1=27.57 \%, \mathrm{C} 18: 2=53.21 \%, \mathrm{C} 18: 3=1.70 \%, \mathrm{C} 20: 5$ $0.16 \%, \mathrm{C} 24: 0=0.31 \%$.

${ }^{3}$ Premix contained $6 \% \mathrm{Zn}$ as $\mathrm{ZnO}, 5 \% \mathrm{Fe}$ as $\mathrm{FeSO}_{4}, 4 \% \mathrm{Mn}$ as $\mathrm{MnO}, 2 \% \mathrm{Cu}$ as $\mathrm{CuSO}_{4}, 0.28 \%$ $\mathrm{Mg}, 0.2 \% \mathrm{I}$ as $\mathrm{Ca}\left(\mathrm{IO}_{3}\right)_{2}\left(\mathrm{H}_{2} \mathrm{O}\right)$, and $0.05 \% \mathrm{Co}$ as $\mathrm{CoCO}_{3}$. ${ }^{4}$ Premix contained $198 \mathrm{~g} / \mathrm{kg}$ monensin (Rumensin, Elanco Animal Health, Indianapolis, IN). ${ }^{5}$ Premix contained $88 \mathrm{~g} / \mathrm{kg}$ tylosin (Tylan, Elanco Animal Health).

${ }^{6}$ Premix contained $29,974 \mathrm{IU} / \mathrm{g}$ vitamin A, 5,995 IU/g vitamin D, and $7.5 \mathrm{lU} / \mathrm{g}$ vitamin $\mathrm{E}$.

Therefore, the objectives of this trial were to evaluate the effect of feeding different concentrations of modified DGS (MDGS) during winter backgrounding and either MDGS or commercial corn gluten feed (CCGF; Sweet Bran, Cargill Corn Milling, Blair, NE) during the finishing phase on raw and cooked ground beef and to evaluate the effectiveness of natural rosemary and green tea extract in the cooked beef samples to counteract differences in lipid oxidation due to animal diet.

\section{MATERIALS AND METHODS}

\section{Dietary Treatments and Product Collection}

All animal protocols performed in this study were approved by the University of Nebraska-Lincoln Institutional Animal Care and Use Committee (Protocol \# 902). Spayed crossbred heifers $(\mathrm{n}=64$; initial $\mathrm{BW}=225 \pm 2$ $\mathrm{kg}$ ) were randomly assigned to a $2 \times 2$ factorial arrangement of dietary treatments that included backgrounding supplementation amount (0.91 or $2.27 \mathrm{~kg}$ of MDGS daily; $146 \mathrm{~d}$ ) while grazing on corn stalks and finishing diet (corn-based diet with either CCGF or MDGS at $40 \%$ diet DM; 134 d; Table 1). Cattle were grazed on corn stalks as a single unit within treatment. Both finishing diets contained $33 \mathrm{mg} / \mathrm{kg}$ monensin (Rumensin, Elanco Animal Health, Indianapolis, IN), and tylosin was provided at $90 \mathrm{mg} /$ heifer daily (Tylan, Elanco Animal Health). Two pens of 8 head were replicated per dietary treatment combination. All cattle were supplemented with DDGS plus solubles at a rate of $0.6 \%$ of $\mathrm{BW}$ during the summer months $(111 \mathrm{~d})$ while grazing on native range grass. The native range grass composition is described in experiment 2 of the study by Buckner et al. (2013). A deferred rotational grazing system was used, as described by Schacht et al. (2011), and stocked at 2.08 animal unit months/ha.

At the time of receiving and before winter backgrounding, heifers were vaccinated against Clostridium chauvoei; Clostridium septicum; Clostridium novyi; Clostridium sordellii; Clostridium perfringens Types B, C, and D; and Histophilus somni (BoviShield Gold, Ultrabac 7/Somubac, Zoetis Inc., Kalamazoo, MI) and Mannheimia haemolytica type A1(One Shot Pasteurella, Zoetis Inc.). Heifers also received an injectable parasiticide for control of gastrointestinal roundworms, lungworms, eyeworms, grubs, suck- 
ing lice, and mange mites (Dextomax, Zoetis Inc.). Cattle were revaccinated 2 wk later (BoviShield Gold and Vision 7/Somnus, Zoetis Inc.) and vaccinated against Moraxella bovis for pinkeye protection (Piliguard Pinkeye-1, Merck Animal Health, Madison, NJ). Heifers were treated with an insecticide pour-on for control of gastrointestinal roundworms, lungworms, grubs sucking lice, and mites (Phonectin, Teva Animal Health, St. Joseph, MO) in February during winter backgrounding. At the beginning of summer grazing, the heifers received an implant containing $40 \mathrm{mg}$ of trenbolone acetate and $8 \mathrm{mg}$ of estradiol (Revalor-G, Merck Animal Health); an insecticide pour-on (Phonectin, Teva Animal Health); and an insecticide ear tag for control of horn flies, face flies, stable flies, house flies, biting lice, and sucking lice (Python MAGNUM, Y-Tex Corp., Cody, WY), and they were revaccinated for pinkeye protection (Piliguard Pinkeye-1, Merck Animal Health). At the beginning of the finishing phase, heifers received an implant containing $200 \mathrm{mg}$ of trenbolone acetate and 20 mg of estradiol (Revalor-200, Merck Animal Health).

Cattle were harvested at a commercial beef processing facility. Carcasses were identified at the time of grading by selecting the first 2 USDA choice carcasses from each pen. An untrimmed beef shoulder clod (IMPS \# 114; USDA, 2014) was collected from the right side of each carcass after fabrication. Clods were vacuum-packed, transported to Loeffel Meat Laboratory at the University of NebraskaLincoln, and stored at $2^{\circ} \mathrm{C}$ until processing on $\mathrm{d} 14$. A total of 16 shoulder clods were collected representing 4 shoulder clods from each dietary treatment group.

\section{Diet Analysis}

Feed samples were collected weekly and composited by month. Samples were stored at $-5^{\circ} \mathrm{C}$ until analysis. Samples were analyzed for $\mathrm{N}$ using a combustion method (LECO TruSpec FP-528, St. Joseph, MI) and for NDF using the procedure outlined by Van Soest et al. (1991) with heat-stable amylase added. Samples were analyzed for ether extract using a biphasic lipid extraction procedure outlined by Bremer (2010). Briefly, samples were heated in a 1:1 mixture of hexane and diethyl ether for $9 \mathrm{~h}$, dilute $\mathrm{HCl}$ was added, and samples were centrifuged at 1,000 $\times$ $g$ for $6 \mathrm{~min}$ at $25^{\circ} \mathrm{C}$ to separate the lipid layer from other liquid. The lipid layer was pipetted off, heated to remove remaining solvent, and weighed. Diet nutrient composition was calculated from analyzed ingredients weighted for inclusion rate.

\section{Cooked Beef Link Manufacture}

On d 14 postmortem, beef shoulder clods were processed. A $0.5-\mathrm{cm}$ slice was taken from the triceps brachii muscle and s.c. fat on the ventral end of each shoulder clod for lean and s.c. fat, respectively, for proximate and fatty acid composition analyses. Each shoulder clod was independently ground through a $1.27-\mathrm{cm}$ plate and then fine ground through a $0.48-\mathrm{cm}$ plate (Model 4732, Ho- bart, Troy, $\mathrm{OH}$ ). The grinder was cleaned of visible materials between each clod. A ground composite sample was taken for proximate and fatty acid composition analyses. The lean, s.c. fat, and composite samples were vacuum packaged separately and stored at $-80^{\circ} \mathrm{C}$ until analysis. The ground clod was divided into three $2.27-\mathrm{kg}$ batches. All treatments contained $0.75 \%$ salt and $0.25 \%$ sodium phosphate (Brifisol 85 instant, BK Giulini Corp., Simi Valley, CA) based on meat block basis. Treatments also contained either $0,0.13$, or $0.20 \%$ of a rosemary and green tea natural plant extract (FORTIUM RGT12 Plus Dry Natural Plant Extract; Kemin, Des Moines, IA) as an antioxidant. These are commonly used ingredients in readyto-eat beef products. Beef and nonmeat ingredients were mixed for 1 min (RM-20, Manica USA, St. Louis, MO), and the mixture was stuffed into 22-mm-diameter skinless links using a hydraulic piston stuffer (Talsa H31P, Talsabell S.A., Valencia, Spain) and Colosimo press (model 200, Gale Colosimo Seasoning Co., South Salt Lake, UT) attachment. Links were placed in individual foil trays for each shoulder clod. Trays were covered with aluminum foil, and links were cooked to an internal temperature of $71^{\circ} \mathrm{C}$ in a smokehouse (Alkar-Rapid Pak, Lodi, WI) with the following program: (1) $65^{\circ} \mathrm{C}$ for $10 \mathrm{~min},(2) 71^{\circ} \mathrm{C}$ for 10 min, (3) $82^{\circ} \mathrm{C}$ for $10 \mathrm{~min}$, and $(4) 88^{\circ} \mathrm{C}$ until internal temperature was reached. Links were placed in zip-top bags (Ziploc Storage Bags, 1 Gallon, S. C. Johnson, Racine, WI) in aerobic conditions and kept in either dark refrigerated storage at $2^{\circ} \mathrm{C}$ or dark frozen storage at $-20^{\circ} \mathrm{C}$ until appropriate sampling days.

\section{Raw Beef Patty Manufacture and Simulated Retail Display}

On d 14 from each ground shoulder clod, fourteen 113-g patties (2 full patties for color analysis and 12 patties for lipid oxidation analysis per shoulder clod) were formed using an 11-cm-diameter hand operated hamburger press. Patties were placed on Styrofoam trays $(13.3 \times 25.6 \times$ $1.4 \mathrm{~cm}$, Styro-Tech, Denver, CO) and overwrapped with oxygen-permeable polyvinyl chloride wrap (Prime Source Meat Film, Prime Source Sanitary Supply, St. George, UT). Packaged patties were placed on a table in a cooler maintained at 0 to $2^{\circ} \mathrm{C}$ under continuous 1,000- to 1,800-lx warm white fluorescence lighting (PHILIPS F32T8/TL741 ALTO 700 Series, 32 WATT B7, Royal Philips Electronics, Amsterdam, the Netherlands) to provide simulated retail display conditions for up to $6 \mathrm{~d}$. On d $0,0.5,1,2$, 4 , and 6 of simulated retail display, 2 patties from each shoulder clod were vacuum packaged and stored at $-80^{\circ} \mathrm{C}$ until evaluation for lipid oxidation.

\section{Fatty Acid Analysis}

Total lipid was extracted following the chloroform-methanol procedure of Folch et al. (1957) for lean, composite, and s.c. fat samples. After extraction, the lipids were converted to fatty acid methyl esters according to Morrison 
and Smith (1964) and Metcalfe et al. (1966). Independently, frozen lean and composite samples from each shoulder clod were frozen in liquid nitrogen and powdered to ensure a homogenized sample using a Waring commercial blender (Model 51BL32, Waring Commercial, Torrington, $\mathrm{CT}$ ). Powdered samples were stored at $-80^{\circ} \mathrm{C}$ until analysis. Subcutaneous fat samples were prepared using a small punch. Fatty acid composition was determined by GLC after fat extraction from samples followed by formation of methyl esters of fatty acids. Samples $(1 \mathrm{~g}$ for lean, $0.33 \mathrm{~g}$ for composite, or $0.1 \mathrm{~g}$ for s.c. fat) were dissolved in $5 \mathrm{~mL}$ of 2:1 chloroform:methanol ( $\mathrm{vol} / \mathrm{vol}$ ) to extract the lipid fraction after vortexing for $5 \mathrm{~s}$ and standing for $1 \mathrm{~h}$ at room temperature. The homogenate was filtered through Whatman \#2 filter paper into a $13 \times 150 \mathrm{~mm}$ screw-cap tube, and the final volume was brought to $10 \mathrm{~mL}$ with $2: 1$ chloroform:methanol mix. Then, $2 \mathrm{~mL}$ of $0.74 \% \mathrm{KCl}$ solution was added to the lipid extract and vortexed for $5 \mathrm{~s}$ to separate extracted proteins. Samples were centrifuged at $1,000 \times g$ for $5 \mathrm{~min}$ at $4^{\circ} \mathrm{C}$. Following centrifugation, the aqueous layer was aspirated and evaporated to dryness under nitrogen at $60^{\circ} \mathrm{C}$ (Folch et al., 1957). Then, $0.5 \mathrm{~mL}$ of $0.5 \mathrm{M} \mathrm{NaOH}$ in methanol was added, vortexed again for $5 \mathrm{~s}$, and heated for $5 \mathrm{~min}$ at $100^{\circ} \mathrm{C}$ under nitrogen for saponification. To methylate the fatty acids, $0.5 \mathrm{~mL}$ of a $14 \%$ (wt/vol) boron trifluoride in methanol solution was added and heated for $5 \mathrm{~min}$ at $100^{\circ} \mathrm{C}$ (Metcalfe et al., 1966). One milliliter of saturated salt solution and $1 \mathrm{~mL}$ of hexane were added and vortexed for $5 \mathrm{~s}$. Following centrifugation at $1,000 \times g$ for $5 \mathrm{~min}$ at $4^{\circ} \mathrm{C}$, the hexane layer was removed and placed in a GLC sampling vial. The sample containing fatty acids in the GLC vial was purged with nitrogen, capped, and stored at $-80^{\circ} \mathrm{C}$ until the sample was read on a Hewlett-Packard Gas Chromatograph (Agilent Technologies, model 5890A series, Santa Clara, CA) attached to a Hewlett-Packard Autosampler (Agilent Technologies, model 6890A series). Fatty acid methyl esters were separated on a fused silica column (Chrompack CP-Sil 88; $0.25 \mathrm{~mm} \times 100 \mathrm{~m}$, Santa Clara, CA), which was placed in an oven programmed from $140^{\circ} \mathrm{C}$ for $10 \mathrm{~min}$ to $220^{\circ} \mathrm{C}$ at a rate of $2^{\circ} \mathrm{C}$ per min and held at $220^{\circ} \mathrm{C}$ for 20 min using helium as a carrier gas with a flow rate of $1 \mathrm{~mL}$ per minute. Total run time was $70 \mathrm{~min}$. The injector and detector were programmed to operate at 270 and $300^{\circ} \mathrm{C}$, respectively. Individual fatty acids of each sample were determined by comparison of retention times with known standards (GLC-68D, GLC-79, GLC-87, GLC-455, and GLC-458, Nu-Chek Prep Inc., Elysian, MN). Fatty acids were expressed as weight percentage value, which were relative proportions of all peaks observed by GLC. Data were converted to milligrams of fatty acid per $100 \mathrm{~g}$ of sample using the measured lipid content of the sample.

\section{Proximate Analysis}

Moisture and total fat of pulverized raw meat samples were determined for lean and composite samples. Two grams of pulverized tissue in duplicate were used to quantify moisture and ash using a LECO thermo-gravimetric analyzer (LECO Corporation, model 604-100-400). Total fat was determined as outlined by AOAC (1990) using the Soxhlet extraction procedure.

\section{Objective Color Evaluation}

The patty color during simulated retail display was measured with a colorimeter (Chroma Meter CR-400; Konica Minolta Sensing Americas Inc., Ramsey, NJ) using a $2^{\circ}$ standard observer and a D65 illuminant. The calibration plate was read through polyvinyl chloride overwrap film because patties were still within the packaging during the color measurement. The color of the 2 patties at 3 locations each was measured, and the resulting measurements were averaged for each sample. Color values were collected for $\mathrm{L}^{*}$ (lightness), $\mathrm{a}^{*}$ (redness), and $\mathrm{b}^{*}$ (yellowness). Color was measured on d $0,0.5,1,2,3,5$, and 6 .

\section{Visual Discoloration Evaluation}

A 5-person trained panel composed of graduate students of the Department of Animal Science at the University of Nebraska-Lincoln visually evaluated the percentage discoloration of raw ground beef patties on d $0,1,2,3,5$, 6 , and 7 of simulated retail display. Panelists had been previously trained to evaluate discoloration of steaks using pictures showing percent discoloration in $10 \%$ increments. Panelists were directed to evaluate the discoloration of the lean portions of the ground beef patties as they were trained to on the steaks. Discoloration was evaluated as percentage surface discoloration ranging from 0 to $100 \%$.

\section{Lipid Oxidation}

The 2-thiobarbuteric acid reactive substance assay (TBARS) described by Ahn et al. (1998), which was a modification of the TBARS assay developed by Buege and Aust (1978), was used to measure the oxidation status of refrigerated and frozen cooked, ground, beef links and fresh ground beef patties over storage time or simulated retail display. Cooked refrigerated links TBARS measurements were taken every $3 \mathrm{~d}$ for $18 \mathrm{~d}$, beginning at $\mathrm{d} 0$. Cooked beef links in frozen storage had TBARS measurements evaluated on d $0,28,56,112,140$, and 168. Raw beef patties in simulated retail display were evaluated for lipid oxidation on d $0,0.5,1,2,4$, and 6 .

To begin TBARS evaluation, $14 \mathrm{~mL}$ of deionized, distilled water and $1 \mathrm{~mL}$ of butylated hydroxyanisole solution (10\% butylated hydroxyanisole in $90 \%$ ethanol) were added to $5 \mathrm{~g}$ of sample. After homogenizing for $15 \mathrm{~s}$ using a Polytron (POLYTRON Kinimatica CH-6010, Luzern, Switzerland), the homogenate was centrifuged at 2,000 $\times$ $g$ for 5 min at $4^{\circ} \mathrm{C}$. One milliliter of homogenate was mixed with $2 \mathrm{~mL}$ of 2-thiobarbituric acid and trichloroacetic acid mixture [15\% trichloroacetic acid (wt/vol) and $20 \mathrm{nM}$ 2-thiobarbituric acid] in double distilled $\mathrm{H}_{2} \mathrm{O}$ and vortexed 
for $5 \mathrm{~s}$. The sample mixture was incubated at $70^{\circ} \mathrm{C}$ in a water bath for $30 \mathrm{~min}$ to develop color. After samples were cooled in a cold-water bath for $10 \mathrm{~min}$, the sample mixture was centrifuged at $2,000 \times g$ for $15 \mathrm{~min}$ at $4^{\circ} \mathrm{C}$. Duplicate $200-\mu \mathrm{L}$ aliquots of each sample were transferred into wells on a 96-well plate, and the absorbance was read at $540 \mathrm{~nm}$ to calculate the milligrams of malonaldehyde per kilogram of tissue using 1,1,3,3-tetraethoxypropane as the standard solution.

\section{Statistical Analysis}

Following examples of previous research that investigated the effects of dietary treatment on beef lipid composition, lipid oxidation, or both (Srinivasan et al., 1998; Mello et al., 2012; Dierks et al., 2017), animal (individual beef shoulder clod) was considered the experimental unit. Dietary treatments were arranged in a $2 \times 2$ factorial arrangement for backgrounding diet (low or high MDGS supplementation) and finishing diet (40\% DM inclusion of MDGS or CCGF). Data for fatty acid composition and proximate composition were analyzed as a $2 \times 2$ factorial treatment arrangement of main effects and their interactions. For lipid oxidation, proximate composition, objective color, and percent discoloration in raw ground patties, data were analyzed for interactions and main effects in a $2 \times 2$ factorial arrangement of background diet and finishing diet with day as a repeated measure using the PROC GLIMMIX procedure of SAS (SAS Institute Inc., Cary, NC). Data for lipid oxidation in cooked links were analyzed as a $2 \times 2 \times 3$ factorial (backgrounding diet $\times$ finishing diet $\times$ added antioxidant quantity) using the PROC GLIMMIX procedure of SAS with repeated measures (day). Using only samples without added antioxidants, an additional analysis of lipid oxidation in cooked links was completed to determine dietary effects separately from antioxidant. These data were analyzed as a $2 \times 2$ factorial using the PROC GLIMMIX procedure of SAS with repeated measures (day) to observe effects of diet on lipid oxidation. When day was used as a repeated measure, a compound symmetry covariance structure was used. All means were separated using the LSMEANS and PDIFF option with a Tukey's honestly significant difference adjustment when level of significance indicated by ANOVA was $P<0.05$.

\section{RESULTS AND DISCUSSION}

\section{Diet and Proximate Composition}

Finishing diets containing MDGS provided more CP, NDF, and fat than the CCGF diet (Table 1). No dietary effects were found for fat or moisture content for the composite or lean beef samples $(P>0.138)$. The average fat content for composite and lean beef samples was 22.7 and $7.8 \%$, respectively. The average moisture content for composite and lean beef samples was 60.0 and $74.3 \%$, respectively.

\section{Fatty Acid Composition}

There was a backgrounding effect on fatty acids in the s.c. fat where there was a lower concentration of C18:0 and a greater amount of C16:1 $(P=0.005$ and 0.020 , respectively; Table 2) in beef from cattle supplemented with greater amounts of MDGS, but no significant backgrounding diet effects $(P>0.05)$ were observed for lean or composite samples. The backgrounding diet effect on fatty acid composition does not fully explain differences in lipid oxidation due to backgrounding diet in cooked beef links. Dierks et al. (2017) also found limited differences in fatty acid profile of ground beef shoulder clods due to backgrounding diets with or without DGS supplementation but only made this analysis in ground composite samples. However, Buttrey et al. (2012) reported greater concentrations of C18:2 in loin steaks from cattle supplemented with DDGS during a stocker phase.

Lean, s.c. fat, and composite samples from cattle finished on the MDGS diet had greater amounts of C18:2 and total PUFA $(P \leq 0.0283$, Table 3$)$ than those fed the CCGF diet. The composite sample also had a finishing effect where cattle finished with MDGS had greater amounts of $\mathrm{C} 16: 1(P=0.043)$ and lesser amounts of $\mathrm{C} 17: 0$ and $\mathrm{C} 17: 1(P=0.002$ and 0.006 , respectively) than the cattle finished on the CCGF diet. These changes in fatty acid composition may be related to differences in lipid oxidation. Because fat depots can have different fatty acid compositions (Jiang et al., 2010) and ground beef contains different depots, this study used 2 different fat depots, s.c. and i.m., and the ground composite for fatty acid analysis to see the effect of type of fat storage. The composite sample would have contained s.c., intermuscular, and i.m. fat. Domenech-Perez (2016) also reported greater total PUFA and 18:2 in beef strip steaks from cattle fed WDGS than from cattle fed a control diet. This also agrees with the research of Gill et al. (2008), where there was an increase in all types of 18:2, total PUFA, and total conjugated linoleic acid in strip steaks from cattle fed either corn or sorghum distillers grain compared with cattle fed steamflaked corn. Vander Pol et al. (2009) reported a greater proportion of C18:2 reached the duodenum when cattle were fed diets containing WDGS than all other diets (corn control, corn control with added corn oil, including corn bran and corn gluten feed, or including corn bran, corn gluten feed and added oil). This indicates that a greater proportion of lipid in diets containing DGS passes the rumen without being biohydrogenated and likely explains the greater concentration of PUFA and C18:2 in beef often reported in studies investigating the effect of feeding DGS in cattle diets.

Supplementation with MDGS during backgrounding had less effect on fatty acid composition of ground beef than including MDGS in the finishing diets. Chao (2015) reported greater PUFA in phospholipid of cattle fed DGS. It may be possible that deposition of fatty acids into phospholipids could occur without detectable differences in total fatty acid composition. 
Table 2. Effect of low or high supplementation concentration $(0.91$ or $2.27 \mathrm{~kg} / \mathrm{head}$ daily, respectively) of modified wet distillers grains during backgrounding on fatty acid composition (mg/100 $\mathrm{g}$ of raw sample) of beef shoulder clod composite, lean, and s.c. fat samples

\begin{tabular}{|c|c|c|c|c|}
\hline \multirow[b]{2}{*}{ Location } & \multicolumn{2}{|c|}{ Backgrounding diet } & \multirow[b]{2}{*}{ SEM } & \multirow[b]{2}{*}{$P$-value } \\
\hline & Low & High & & \\
\hline \multicolumn{5}{|l|}{ Composite $^{1}$} \\
\hline $\mathrm{C} 16: 0, \mathrm{mg} / 100 \mathrm{~g}$ & 5,052 & 5,091 & 342 & 0.909 \\
\hline $\mathrm{C} 16: 1, \mathrm{mg} / 100 \mathrm{~g}$ & 652.1 & 685.8 & 43.7 & 0.596 \\
\hline $\mathrm{C} 17: 0, \mathrm{mg} / 100 \mathrm{~g}$ & 324.3 & 326.0 & 17.1 & 0.945 \\
\hline $\mathrm{C} 17: 1, \mathrm{mg} / 100 \mathrm{~g}$ & 281.4 & 297.1 & 22.5 & 0.630 \\
\hline $\mathrm{C} 18: 0, \mathrm{mg} / 100 \mathrm{~g}$ & 3,527 & 3,171 & 277 & 0.223 \\
\hline $\mathrm{C} 18: 1, \mathrm{mg} / 100 \mathrm{~g}$ & 10,670 & 10,664 & 504 & 0.994 \\
\hline $\mathrm{C} 18: 2, \mathrm{mg} / 100 \mathrm{~g}$ & 623.5 & 648.7 & 64.5 & 0.702 \\
\hline $\mathrm{SFA},{ }^{2} \mathrm{mg} / 100 \mathrm{~g}$ & 9,553 & 9,255 & 435 & 0.636 \\
\hline PUFA,${ }^{3} \mathrm{mg} / 100 \mathrm{~g}$ & 695.6 & 740.2 & 45.7 & 0.503 \\
\hline MUFA, ${ }^{4} \mathrm{mg} / 100 \mathrm{~g}$ & 12,163 & 12,236 & 760 & 0.926 \\
\hline UFA,${ }^{5} \mathrm{mg} / 100 \mathrm{~g}$ & 12,853 & 12,903 & 532 & 0.948 \\
\hline SFA:UFA & 0.744 & 0.717 & 0.015 & 0.236 \\
\hline \multicolumn{5}{|l|}{ Lean $^{1}$} \\
\hline $\mathrm{C} 16: 0, \mathrm{mg} / 100 \mathrm{~g}$ & 1,614 & 1,745 & 157 & 0.567 \\
\hline $\mathrm{C} 16: 1, \mathrm{mg} / 100 \mathrm{~g}$ & 317.7 & 331.0 & 62.9 & 0.838 \\
\hline $\mathrm{C} 17: 0, \mathrm{mg} / 100 \mathrm{~g}$ & 113.5 & 116.7 & 21.2 & 0.914 \\
\hline $\mathrm{C} 17: 1, \mathrm{mg} / 100 \mathrm{~g}$ & 97.5 & 104.1 & 12.1 & 0.695 \\
\hline $\mathrm{C} 18: 0, \mathrm{mg} / 100 \mathrm{~g}$ & 937.4 & 975.7 & 96.2 & 0.783 \\
\hline $\mathrm{C} 18: 1, \mathrm{mg} / 100 \mathrm{~g}$ & 3,574 & 3,699 & 340 & 0.800 \\
\hline $\mathrm{C} 18: 2, \mathrm{mg} / 100 \mathrm{~g}$ & 336.9 & 338.5 & 34.8 & 0.974 \\
\hline $\mathrm{SFA},{ }^{2} \mathrm{mg} / 100 \mathrm{~g}$ & 2,849 & 3,042 & 388 & 0.628 \\
\hline PUFA,${ }^{3} \mathrm{mg} / 100 \mathrm{~g}$ & 421.4 & 417.0 & 43.6 & 0.944 \\
\hline MUFA, ${ }^{4} \mathrm{mg} / 100 \mathrm{~g}$ & 4,190 & 4,548 & 412 & 0.551 \\
\hline UFA,${ }^{5} \mathrm{mg} / 100 \mathrm{~g}$ & 4,611 & 4,967 & 414 & 0.558 \\
\hline SFA:UFA & 0.624 & 0.612 & 0.039 & 0.783 \\
\hline \multicolumn{5}{|l|}{ Subcutaneous fat ${ }^{1}$} \\
\hline $\mathrm{C} 16: 0, \mathrm{mg} / 100 \mathrm{~g}$ & 22,879 & 23,653 & 418 & 0.215 \\
\hline $\mathrm{C} 16: 1, \mathrm{mg} / 100 \mathrm{~g}$ & $4,273^{b}$ & $5,743^{a}$ & 387 & 0.020 \\
\hline $\mathrm{C} 17: 0, \mathrm{mg} / 100 \mathrm{~g}$ & 1,295 & 1,280 & 76 & 0.842 \\
\hline $\mathrm{C} 17: 1, \mathrm{mg} / 100 \mathrm{~g}$ & 1,240 & 1,497 & 94 & 0.075 \\
\hline $\mathrm{C} 18: 0, \mathrm{mg} / 100 \mathrm{~g}$ & $11,894^{a}$ & $8,939^{b}$ & 847 & 0.005 \\
\hline $\mathrm{C} 18: 1, \mathrm{mg} / 100 \mathrm{~g}$ & 51,242 & 51,340 & 714 & 0.924 \\
\hline $\mathrm{C} 18: 2, \mathrm{mg} / 100 \mathrm{~g}$ & 1,974 & 1,990 & 144 & 0.940 \\
\hline $\mathrm{SFA},{ }^{2} \mathrm{mg} / 100 \mathrm{~g}$ & 39,203 & 36,911 & 830 & 0.075 \\
\hline PUFA, ${ }^{3} \mathrm{mg} / 100 \mathrm{~g}$ & 1,974 & 1,990 & 144 & 0.940 \\
\hline MUFA,${ }^{4} \mathrm{mg} / 100 \mathrm{~g}$ & 58,279 & 60,552 & 836 & 0.079 \\
\hline UFA,${ }^{5} \mathrm{mg} / 100 \mathrm{~g}$ & 60,253 & 62,541 & 825 & 0.074 \\
\hline SFA:UFA & 0.651 & 0.592 & 0.022 & 0.079 \\
\hline
\end{tabular}

a,b Means in the same row with unlike superscripts differ $(P<0.05)$.

${ }^{1}$ Ground composite, lean, and s.c. fat samples from the beef shoulder clods. $\mathrm{n}=8$ per diet. ${ }^{2} \mathrm{C} 14: 0, \mathrm{C} 15: 0, \mathrm{C} 16: 0, \mathrm{C} 17: 0, \mathrm{C} 18: 0$.

${ }^{3} \mathrm{C} 18: 2, \mathrm{C} 20: 4$.

${ }^{4} \mathrm{C} 14: 1, \mathrm{C} 16: 1, \mathrm{C} 17: 1, \mathrm{C} 18: 1 \mathrm{~T}$ (trans-vaccenic acid), C18:1, C18:1V (vaccenic acid), C20:1. ${ }^{5} U F A=$ unsaturated fatty acids: C14:1, C16:1, C17:1, C18:1T, C18:1, C18:1V, C18:2, C20:1, C20:4. 
Table 3. Effect of finishing diets containing commercial corn gluten feed or modified distillers grains with solubles on fatty acid composition ( $\mathrm{mg}$ of fatty acid/100 $\mathrm{g}$ of raw sample) of beef shoulder clod composite, lean, and s.c. fat samples

\begin{tabular}{|c|c|c|c|c|}
\hline \multirow[b]{2}{*}{ Location } & \multicolumn{2}{|c|}{ Finishing diet } & \multirow[b]{2}{*}{ SEM } & \multirow[b]{2}{*}{$P$-value } \\
\hline & CCGF $^{1}$ & MDGS $^{1}$ & & \\
\hline \multicolumn{5}{|l|}{ Composite ${ }^{2}$} \\
\hline $\mathrm{C} 16: 0, \mathrm{mg} / 100 \mathrm{~g}$ & 5,372 & 4,770 & 242 & 0.104 \\
\hline $\mathrm{C} 16: 1, \mathrm{mg} / 100 \mathrm{~g}$ & $599.8^{\mathrm{b}}$ & $740.0^{\mathrm{a}}$ & 61.7 & 0.043 \\
\hline $\mathrm{C} 17: 0, \mathrm{mg} / 100 \mathrm{~g}$ & $373.5^{a}$ & $276.9^{b}$ & 17.1 & 0.002 \\
\hline $\mathrm{C} 17: 1, \mathrm{mg} / 100 \mathrm{~g}$ & $341.6^{\mathrm{b}}$ & $237.0^{\mathrm{a}}$ & 31.8 & 0.006 \\
\hline $\mathrm{C} 18: 0, \mathrm{mg} / 100 \mathrm{~g}$ & 3,477 & 3,222 & 196 & 0.375 \\
\hline $\mathrm{C} 18: 1, \mathrm{mg} / 100 \mathrm{~g}$ & 11,170 & 10,163 & 504 & 0.183 \\
\hline $\mathrm{C} 18: 2, \mathrm{mg} / 100 \mathrm{~g}$ & $524.3^{b}$ & $748.0^{\mathrm{a}}$ & 45.6 & 0.005 \\
\hline $\mathrm{SFA},{ }^{3} \mathrm{mg} / 100 \mathrm{~g}$ & 9,894 & 8,914 & 614 & 0.137 \\
\hline PUFA, ${ }^{4} \mathrm{mg} / 100 \mathrm{~g}$ & $592.1^{b}$ & $843.7^{a}$ & 45.7 & 0.002 \\
\hline MUFA, ${ }^{5} \mathrm{mg} / 100 \mathrm{~g}$ & 12,893 & 11,506 & 538 & 0.093 \\
\hline UFA, ${ }^{6} \mathrm{mg} / 100 \mathrm{~g}$ & 13,407 & 12,349 & 531 & 0.185 \\
\hline SFA:UFA & 0.739 & 0.722 & 0.015 & 0.451 \\
\hline \multicolumn{5}{|l|}{ Lean $^{2}$} \\
\hline $\mathrm{C} 16: 0, \mathrm{mg} / 100 \mathrm{~g}$ & 1,565 & 1,794 & 157 & 0.324 \\
\hline $\mathrm{C} 16: 1, \mathrm{mg} / 100 \mathrm{~g}$ & 305.2 & 343.5 & 62.9 & 0.557 \\
\hline $\mathrm{C} 17: 0, \mathrm{mg} / 100 \mathrm{~g}$ & 97.0 & 133.2 & 21.2 & 0.236 \\
\hline $\mathrm{C} 17: 1, \mathrm{mg} / 100 \mathrm{~g}$ & 95.3 & 106.3 & 12.1 & 0.517 \\
\hline C18:0, mg/100 g & 881.3 & $1,031.7$ & 96.2 & 0.291 \\
\hline $\mathrm{C} 18: 1, \mathrm{mg} / 100 \mathrm{~g}$ & 3,246 & 4,027 & 340 & 0.131 \\
\hline $\mathrm{C} 18: 2, \mathrm{mg} / 100 \mathrm{~g}$ & $258.9^{b}$ & $416.5^{a}$ & 34.8 & 0.008 \\
\hline $\mathrm{SFA},{ }^{3} \mathrm{mg} / 100 \mathrm{~g}$ & 2,741 & 3,149 & 388 & 0.315 \\
\hline PUFA, ${ }^{4} \mathrm{mg} / 100 \mathrm{~g}$ & $338.3^{b}$ & $500.1^{a}$ & 43.6 & 0.022 \\
\hline MUFA,${ }^{5} \mathrm{mg} / 100 \mathrm{~g}$ & 3,958 & 4,781 & 412 & 0.184 \\
\hline UFA, ${ }^{6} \mathrm{mg} / 100 \mathrm{~g}$ & 4,296 & 5,280 & 414 & 0.118 \\
\hline SFA:UFA & 0.638 & 0.598 & 0.039 & 0.315 \\
\hline \multicolumn{5}{|l|}{ Subcutaneous fat ${ }^{2}$} \\
\hline $\mathrm{C} 16: 0, \mathrm{mg} / 100 \mathrm{~g}$ & 23,423 & 23,109 & 418 & 0.606 \\
\hline $\mathrm{C} 16: 1, \mathrm{mg} / 100 \mathrm{~g}$ & 5,409 & 4,607 & 387 & 0.169 \\
\hline $\mathrm{C} 17: 0, \mathrm{mg} / 100 \mathrm{~g}$ & 1,349 & 1,225 & 76 & 0.131 \\
\hline $\mathrm{C} 17: 1, \mathrm{mg} / 100 \mathrm{~g}$ & $1,472^{a}$ & $1,165^{b}$ & 94 & 0.010 \\
\hline $\mathrm{C} 18: 0, \mathrm{mg} / 100 \mathrm{~g}$ & 9,793 & 11,041 & 847 & 0.166 \\
\hline $\mathrm{C} 18: 1, \mathrm{mg} / 100 \mathrm{~g}$ & 51,166 & 51,415 & 714 & 0.809 \\
\hline $\mathrm{C} 18: 2, \mathrm{mg} / 100 \mathrm{~g}$ & $1,728^{b}$ & $2,235^{a}$ & 144 & 0.028 \\
\hline $\mathrm{SFA},{ }^{3} \mathrm{mg} / 100 \mathrm{~g}$ & 37,740 & 38,374 & 830 & 0.599 \\
\hline PUFA, ${ }^{4} \mathrm{mg} / 100 \mathrm{~g}$ & $1,728^{b}$ & $2,235^{a}$ & 144 & 0.028 \\
\hline MUFA,${ }^{5} \mathrm{mg} / 100 \mathrm{~g}$ & 59,953 & 58,878 & 836 & 0.381 \\
\hline UFA, ${ }^{6} \mathrm{mg} / 100 \mathrm{~g}$ & 61,681 & 61,113 & 825 & 0.635 \\
\hline SFA:UFA & 0.615 & 0.630 & 0.022 & 0.623 \\
\hline
\end{tabular}

a,bMeans in the same row with unlike superscripts differ $(P<0.05)$.

${ }^{1} \mathrm{CCGF}=$ commercial corn gluten feed (Sweet Bran, Cargill Corn Milling, Blair, NE); MDGS = modified distillers grains plus solubles.

${ }^{2}$ Ground composite, lean, and s.c. fat samples from the beef shoulder clods. $n=8$ per diet. ${ }^{3} \mathrm{C} 14: 0, \mathrm{C} 15: 0, \mathrm{C} 16: 0, \mathrm{C} 17: 0, \mathrm{C} 18: 0$.

${ }^{4} \mathrm{C} 18: 2$.

${ }^{5}$ C14:1, C16:1, C17:1, C18:1T (trans-vaccenic acid), C18:1, C18:1V (vaccenic acid), C20:1. ${ }^{6}$ UFA = unsaturated fatty acids: C14:1, C16:1, C17:1, C18:1T, C18:1, C18:1V, C18:2, C20:1, C20:4. 


\section{Lipid Oxidation-Raw Patties}

Lipid oxidation increased $(P<0.001)$ during simulated retail display time (Table 4 ), but neither backgrounding nor finishing diet affected lipid oxidation of raw ground beef patties $(P=0.53$ and 0.47 , respectively, data not shown). This agrees with a companion study conducted on strip loin steaks from the same group of cattle where there were no dietary effects on lipid oxidation (Sudbeck et al., 2014). In contrast, Koger et al. (2010) observed greater lipid oxidation on $\mathrm{d} 7$ of retail display in ground beef from cattle finished on either DDGS or WDGS (40\% inclusion, DM basis) than in ground beef from cattle fed the control diet. Grinding meat disrupts the phospholipid membranes and allows greater exposure of fatty acids to oxygen, thus increasing the rate of lipid oxidation in ground products compared with intact steaks (Sato and Hegarty, 1971). It may be that no dietary differences were observed for lipid oxidation in raw patties because the oxygen environment after grinding provided an optimal environment for lipid oxidation.

\section{Objective Color and Discoloration in Raw Patties}

No backgrounding diet effects were found for objective color measures $(P>0.48)$. For objective color, both a* and $\mathrm{b}^{*}$ values decreased $(P<0.001)$ over time regardless of backgrounding or finishing diet (Table 5). Both finishing diet and day of simulated retail display had an effect $(P \leq 0.03)$ on $\mathrm{L}^{*}$ values. Patties from heifers fed MDGS had lower $(P=0.03) \mathrm{L}^{*}$ values than heifers fed CCGF during the finishing phase (Table 5), and $\mathrm{L}^{*}$ increased $(P<0.001)$ as days of simulated retail display increased, independent of diet (Table 5). Conversely, Koger et al. (2010) did not see any differences in objective color values due to finishing diet.

No backgrounding diet effects were found for subjective visual discoloration in raw ground beef patties $(P>0.51)$. There was a finishing diet by day of simulated retail display interaction $(P<0.001)$ for percent discoloration of ground beef patties; patties from heifers fed MDGS had
Table 4. Effect of day of simulated retail display on lipid oxidation in raw ground beef patties ( $n=16$ per time point)

\begin{tabular}{lc} 
Day & Malonaldehyde, $\mathbf{~ m g} / \mathbf{k g}$ of tissue \\
\hline 0 & $1.38^{\mathrm{e}}$ \\
0.5 & $1.64^{\mathrm{ed}}$ \\
1 & $2.38^{\mathrm{dc}}$ \\
2 & $3.11^{\mathrm{c}}$ \\
4 & $6.24^{\mathrm{b}}$ \\
6 & $10.43^{\mathrm{a}}$ \\
SEM & $0.37^{-}$ \\
P-value & $<0.001$
\end{tabular}

${ }^{\mathrm{a}-\mathrm{e} M e a n s}$ in the same column with unlike superscripts differ $(P<0.05)$.

a greater $(P \leq 0.02)$ discoloration on $\mathrm{d} 3,5$, and 6 than patties from heifers finished with CCGF (all other days were not different; $P \geq 0.19$; Figure 1). Koger et al. (2010) did not observe a finishing diet effect on discoloration of ground beef from cattle fed DGS compared with corn; however, discoloration in their study was only analyzed on d 0,2 , and 7 , and cattle were not supplemented with DGS during any other phase of production. In a study using the same group of cattle, Sudbeck et al. (2014) found that strip loins from cattle fed on a finishing diet containing MDGS discolored sooner than those from cattle fed finishing diets contained CCGF. Furthermore, when cattle were supplemented with greater amounts of MDGS and finished on CCGF, steaks discolored earlier in retail display than steaks from cattle supplemented with lower amounts of DGS during backgrounding (Sudbeck et al., 2014). Beef patties discolored at a faster rate than strip steaks from the same dietary treatments in a companion study (Sudbeck et al., 2014). This is expected because grinding introduces oxygen throughout the product and disrupts membranes, creating an atmosphere more prone to lipid oxidation. The results of this trial suggest that although there were no differences in lipid oxidation of raw ground beef patties due to diet, ground beef from heif-

Table 5. Effect of finishing diet and time of simulated retail display on objective color of raw ground beef patties

\begin{tabular}{|c|c|c|c|c|c|c|c|c|c|c|c|}
\hline \multirow[b]{2}{*}{ Color values } & \multicolumn{2}{|c|}{ Diet $^{1}$} & \multirow[b]{2}{*}{ SEM } & \multicolumn{7}{|c|}{ Day of simulated retail display } & \multirow[b]{2}{*}{ SEM } \\
\hline & CCGF & MDGS & & 0 & 0.5 & 1 & 2 & 3 & 5 & 6 & \\
\hline$L^{*}$ & $53.01^{a}$ & $51.73^{b}$ & 0.41 & $51.69^{v w}$ & $52.3^{v}$ & $51.54^{\mathrm{vw}}$ & $52.43^{\text {uv }}$ & $52.61^{\text {uv }}$ & $53.55^{\text {tu }}$ & $53.81^{\mathrm{t}}$ & 0.48 \\
\hline$a^{*}$ & 15.07 & 14.91 & 0.41 & $23.79^{t}$ & $19.35^{u}$ & $16.80^{\vee}$ & $13.27^{w}$ & $10.43^{x}$ & $8.19^{y}$ & $7.09^{z}$ & 0.40 \\
\hline$b^{*}$ & 10.49 & 10.42 & 0.11 & $12.16^{t}$ & $10.75^{u}$ & $9.86^{w}$ & $9.59^{x}$ & $9.58^{x}$ & $10.13^{w}$ & $10.44^{v}$ & 0.12 \\
\hline
\end{tabular}

a,b Means of color measures for diet with unlike superscripts differ $(P<0.05)$.

${ }^{\mathrm{t}-z}$ Means of color measures for days of simulated retail display with unlike superscripts differ $(P<0.05)$.

${ }^{1} \mathrm{CCGF}=$ commercial corn gluten feed (Sweet Bran, Cargill Corn Milling, Blair, NE); MDGS = modified distillers grains plus solubles. 
ers finished with MDGS discolored at a greater rate than ground beef from heifers finished with CCGF.

\section{Lipid Oxidation of Cooked Links in Refrigerated Storage}

When data were analyzed using backgrounding diet by finishing diet by antioxidant by storage time, an antioxidant concentration by day of refrigerated storage interaction $(P<0.05)$ was observed for refrigerated cooked link lipid oxidation (Figure 2); however, no dietary treatment interactions or main effects $(P>0.16)$ were observed. The lack of dietary effects was likely due to the addition of rosemary and green tea extract, which may have masked any dietary effects on lipid oxidation in all samples. In the full analysis, cooked beef links with no added rosemary and green tea extract in refrigerated storage were more oxidized at $9,12,15$, and $18 \mathrm{~d}(P \leq 0.001$ for all $)$ than were links from any treatments containing antioxidants on any day of storage (Figure 2). There were no $(P>0.05)$ differences in lipid oxidation between cooked beef links with 0.13 or $0.20 \%$ of added rosemary and green tea extract on any day of refrigerated storage. The sensory perception threshold of lipid oxidation has been reported to be between 1 and $2.2 \mathrm{mg}$ of malonaldehyde $/ \mathrm{kg}$ of sample (Tarladgis et al., 1960; Greene and Cumuze, 1982; Campo et al., 2006). Ahn et al. (2007) determined that cooked ground beef with no added antioxidants was already above the general perception of the upper threshold of $2 \mathrm{mg}$ of malonaldehyde $/ \mathrm{kg}$ of sample at d 0 , and was significantly higher than ground beef with grape seed extract, pine bark extract, or oleoresin of rosemary at all time periods. Cooked ground beef with grape seed extract, pine bark extract, and rosemary oleoresin added were below the threshold through $9 \mathrm{~d}$ of refrigerated storage. Results from the current study indicate that cooked ground beef

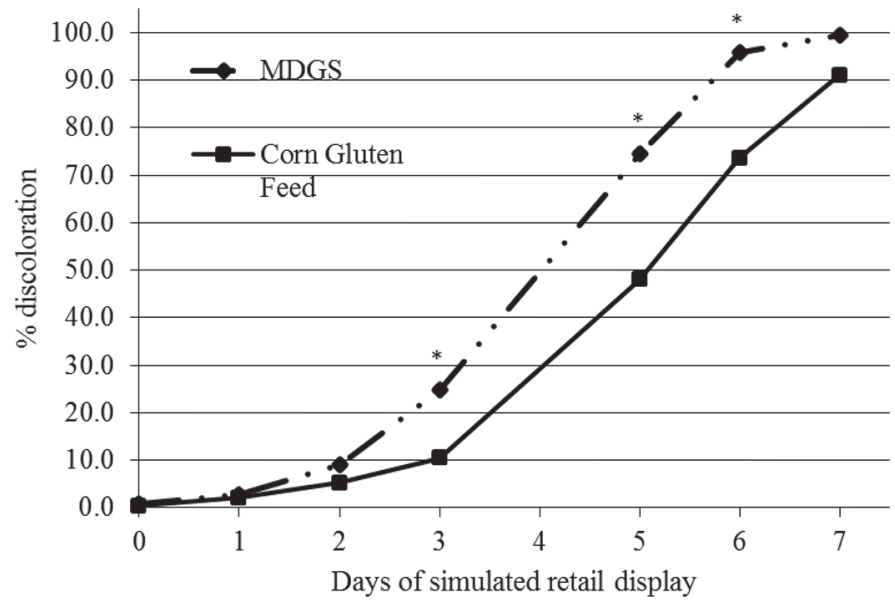

Figure 1. Effect of feeding commercial corn gluten feed (Sweet Bran, Cargill Corn Milling, Blair, NE) or modified distillers grains plus solubles (MDGS) during finishing on visual discoloration of raw ground beef patties in simulated retail display $(\mathrm{SEM}=4.38$; $\mathrm{n}=8$ for each finishing diet and day of simulated storage). *Days where treatments differ $(P<0.05)$. links with the addition of rosemary and green tea extract at 0.13 or $0.20 \%$ were below this threshold for up to $18 \mathrm{~d}$ of refrigerated storage.

When only samples with $0 \%$ added rosemary and green tea extract were analyzed to determine dietary effects, significant winter backgrounding diet by day of storage $(P=0.008)$ and finishing diet by day of storage $(P=$ $0.02)$ interactions were identified. Winter backgrounding supplementation rate had no effect $(P>0.05)$ on lipid oxidation of cooked ground beef in refrigerated storage on $\mathrm{d} 0,3$, and 6 of refrigerated storage, but cattle fed $2.27 \mathrm{~kg}$ of MDGS daily during backgrounding had greater lipid oxidation than cattle fed $0.91 \mathrm{~kg}$ of MDGS on d 9, 12 , and $18(P<0.02$; Figure 3$)$. For the finishing diet by day of storage interaction, there was an increase in lipid oxidation for d $0,3,6,9$, and 12 for cattle fed MDGS, whereas cattle finished on CCGF had little increase in oxidation until d 12; however, only on d 9 was the oxidation of beef from cattle fed MDGS greater than those fed CCGF $(P=0.02$; Figure 4$)$. This suggests that feeding MDGS at any point in production can increase lipid oxidation, but backgrounding supplementation at higher rates may have a greater effect. Dierks et al. (2017) also found that supplementing cattle with greater amounts of DGS during backgrounding resulted in greater lipid oxidation in cooked beef patties, but this was not accompanied by changes in fatty acid composition. This could be a further indication that changes in phospholipid composition, as reported by Chao (2015), could be related to greater lipid oxidation. Dierks et al. (2017) found that finishing cattle with a diet including distillers grain tended to decrease lipid oxidation, which is in contrast to this study. Gunn et al. (2009) did not see a finishing diet effect on lipid oxidation in raw top round samples; however, the samples were aged for $7 \mathrm{~d}$ in a vacuum package, which limited expo-

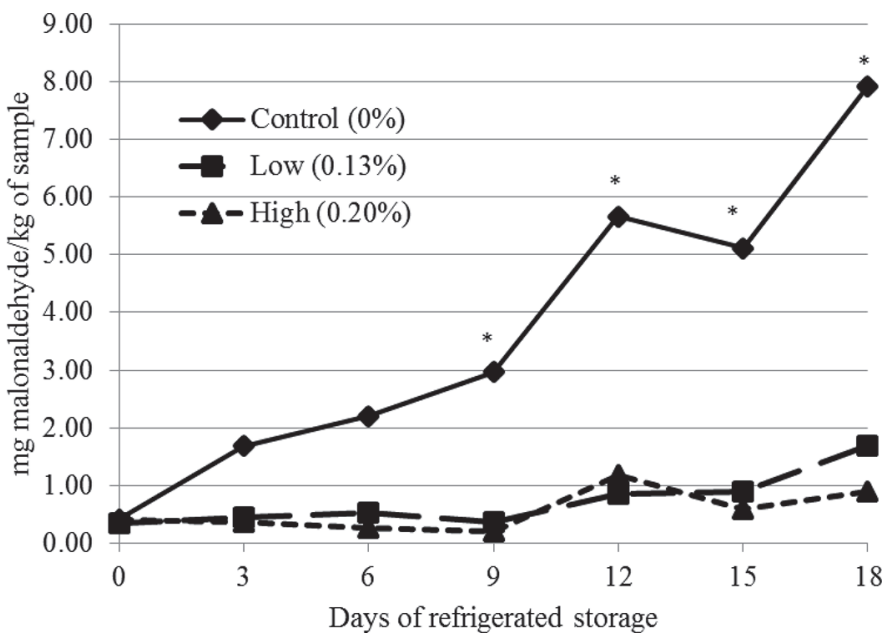

Figure 2. Effect of adding $0,0.13$, or $0.20 \%$ of a rosemary and green tea natural plant extract on the lipid oxidation (mg of malonaldehyde/kg of sample) in cooked beef links during refrigerated storage (SEM $=0.66 ; n=16$ for each antioxidant treatment and day combination). *Days where control is greater than antioxidant treatments $(P<0.05)$. 


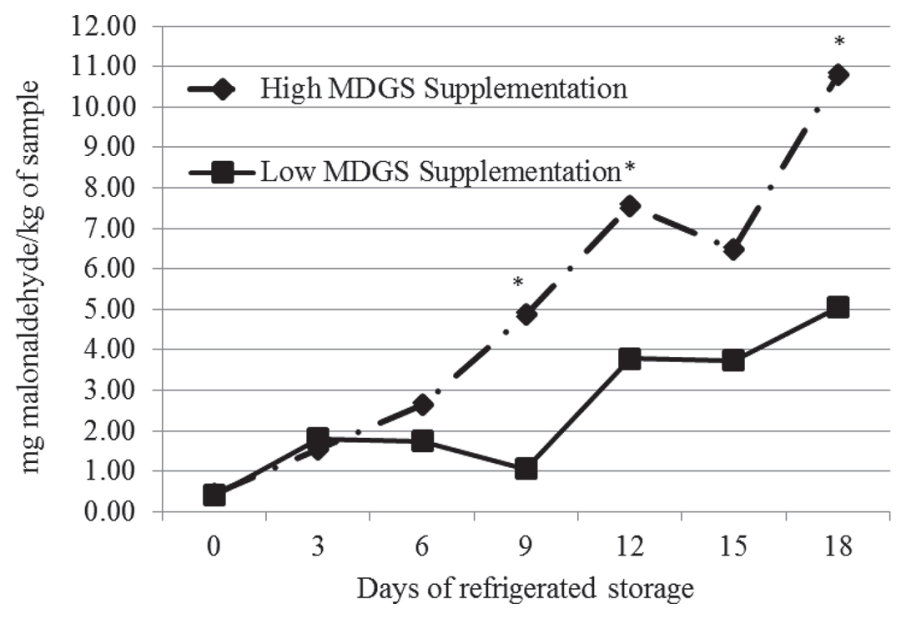

Figure 3. Effect of amount of supplementation of modified distillers grains with solubles (MDGS; 0.91 or $2.27 \mathrm{~kg} / \mathrm{head}$ daily, DM basis) during backgrounding on lipid oxidation (mg of malonaldehyde/kg of sample) in cooked beef links during refrigerated storage (SEM $=0.59 ; \mathrm{n}=8$ for each supplementation treatment and day of storage). ${ }^{*}$ Days where treatments differ $(P$ $<0.05)$.

sure to oxygen. Comminution and cooking likely intensify the susceptibility of beef from cattle supplemented with MDGS to lipid oxidation, hence the increase in TBARS values of beef from cattle supplemented with MDGS during finishing earlier in storage (Sato and Hegarty, 1971; Min et al., 2010). This concept also applies to beef from cattle supplemented with higher concentrations of MDGS during backgrounding. Despite this, regardless of diet, all cooked beef links without rosemary and green tea extract regardless of diet exceeded the $2 \mathrm{mg}$ of malonaldehyde $/ \mathrm{kg}$ of sample threshold after $\mathrm{d} 6$ of refrigerated storage, thus highlighting the benefits of added rosemary and green tea extract.

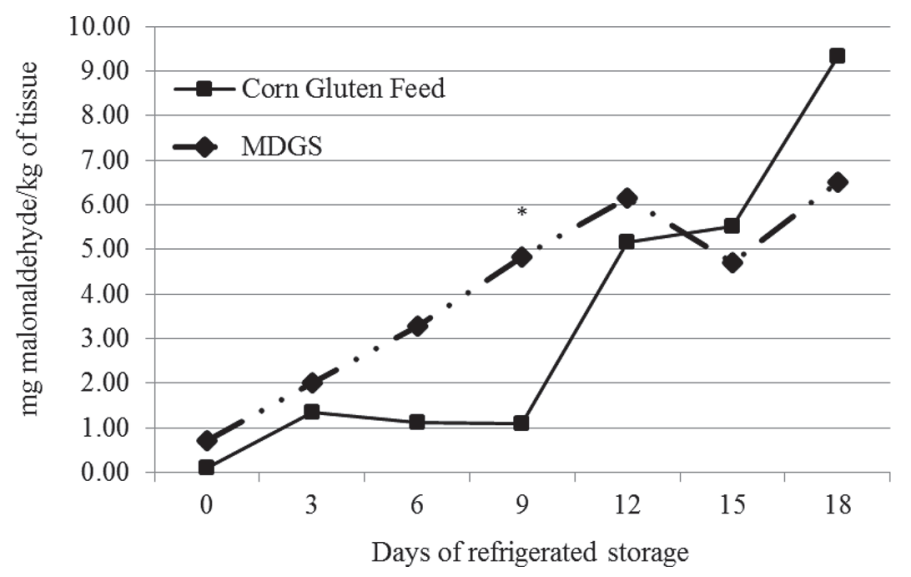

Figure 4. Effect of feeding commercial corn gluten feed (Sweet Bran, Cargill Corn Milling, Blair, NE) or modified distillers grains plus solubles (MDGS) during finishing on lipid oxidation (mg of malonaldehyde/kg of sample) in cooked beef links during refrigerated storage $(S E M=0.59 ; n=8$ for each finishing diet and day of storage). *Days where treatments differ $(P<0.05)$.

\section{Lipid Oxidation of Cooked Links in Frozen Storage}

For beef links in frozen storage, there was an antioxidant by time interaction $(P<0.001)$, where cooked beef links with 0.13 and $0.20 \%$ added rosemary and green tea extract were less oxidized than the cooked beef links with $0 \%$ added rosemary and green tea extract on all days except d 0 (Figure 5). No differences were found between samples with 0.13 or $0.20 \%$ added rosemary and green tea extract at any sampling time. This is in agreement with the results from beef links in refrigerated storage in which no differences in lipid oxidation were observed among 0.13 and $0.20 \%$ rosemary and green tea extract concentrations. All cooked link samples with added rosemary and green tea extract were below the $2 \mathrm{mg}$ of malonaldehyde $/ \mathrm{kg}$ of sample threshold. Very little increase in lipid oxidation was seen beyond d 28 , indicating that frozen storage slowed the rate of lipid oxidation.

In frozen cooked ground beef links, diet did not have any effect on oxidation in the full backgrounding diet $x$ finishing diet $x$ antioxidant $x$ storage time analysis. As with refrigerated cooked beef links, a subsequent analysis was conducted using samples without added rosemary and green tea extract to determine the dietary effect on lipid oxidation in frozen beef links. Interactions were observed for backgrounding diet by day of storage and finishing diet by day of storage $(P=0.02$ and $P=0.01$, respectively). Lipid oxidation increased from d 0 to 28 of frozen storage in cooked beef links from cattle fed both backgrounding supplements. After d 28, lipid oxidation of cooked beef links from cattle fed the higher supplementation of MDGS during backgrounding continued to increase with storage time, whereas cooked beef links from cattle fed the low supplementation plateaued. However, d 168 was the only day with a significant difference $(P=0.04$;

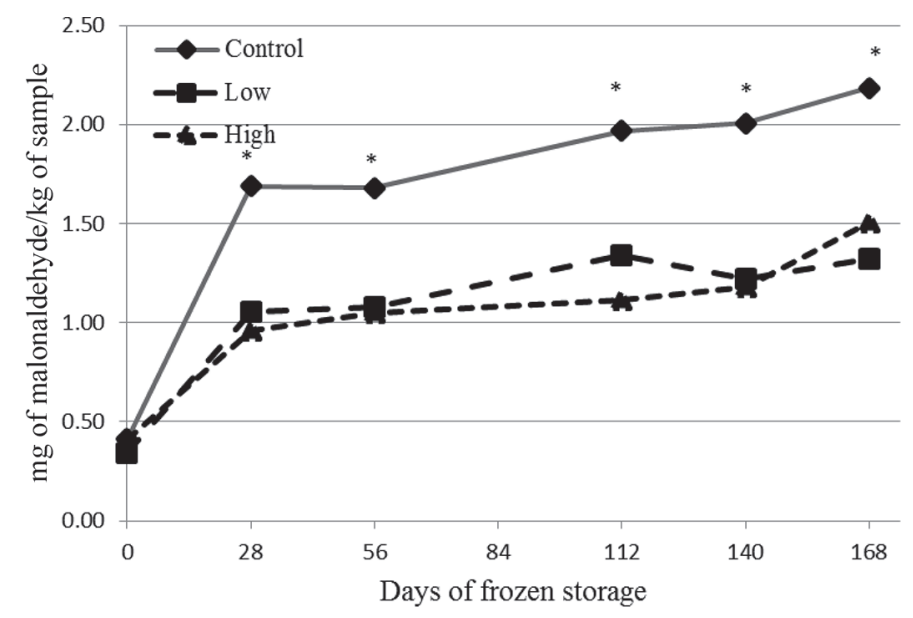

Figure 5. Effect of adding $0 \%$ (control), $0.13 \%$ (low), or $0.20 \%$ (high) of a rosemary and green tea natural plant extract as an antioxidant on the lipid oxidation ( $\mathrm{mg}$ of malonaldehyde/kg of sample) in cooked beef links during frozen storage (SEM $=0.14$; $\mathrm{n}=16$ for each antioxidant quantity and day of storage). *Days where control is greater than antioxidant treatments $(P<0.05)$. 
Table 6. Interactions of days of storage $\times$ backgrounding diet and days of storage $\times$ finishing diet on lipid oxidation ${ }^{1}$ in frozen, cooked beef links ${ }^{1}$

\begin{tabular}{|c|c|c|c|c|c|c|}
\hline \multirow[b]{2}{*}{ Day } & \multicolumn{2}{|c|}{ Backgrounding² } & \multirow[b]{2}{*}{ SEM } & \multicolumn{2}{|c|}{ Finishing $^{3}$} & \multirow[b]{2}{*}{ SEM } \\
\hline & Low & High & & CCGF & MDGS & \\
\hline & $0.40^{d}$ & $0.43^{d}$ & 0.19 & $0.11^{z}$ & $0.71^{y}$ & 0.19 \\
\hline 28 & $1.68^{\mathrm{bc}}$ & $1.70^{\mathrm{bc}}$ & 0.30 & $1.78^{w x}$ & $1.6^{\mathrm{wx}}$ & 0.30 \\
\hline 56 & $1.71^{\mathrm{bc}}$ & $1.66^{\circ}$ & 0.14 & $1.25^{x}$ & $2.13^{w}$ & 0.15 \\
\hline 112 & $1.75^{\mathrm{bc}}$ & $2.18^{a b}$ & 0.19 & $1.85^{w}$ & $2.08^{w}$ & 0.19 \\
\hline 140 & $1.74^{\mathrm{bc}}$ & $2.27^{a b}$ & 0.20 & $1.96^{w}$ & $2.05^{w}$ & 0.20 \\
\hline 168 & $1.72^{\mathrm{bc}}$ & $2.65^{\mathrm{a}}$ & 0.28 & $2.15^{w}$ & $2.22^{w}$ & 0.28 \\
\hline
\end{tabular}

${ }^{a-d}$ Means within the backgrounding phase with unlike superscripts differ $(P<0.05)$.

${ }^{w-z}$ Means within the finishing phase with unlike superscripts differ $(P<0.05)$.

${ }^{1} \mathrm{mg}$ of malonaldehyde/kg of sample. $\mathrm{n}=8$ for each diet and day combination.

${ }^{2}$ Low $=0.91 \mathrm{~kg} / \mathrm{head}$ daily supplementation of modified distillers grains plus solubles (MDGS); High $=2.27 \mathrm{~kg} /$ head daily supplementation of MDGS.

${ }^{3}$ CCGF = commercial corn gluten feed (Sweet Bran, Cargill Corn Milling, Blair, NE).

Table 6). Cooked beef links from cattle finished on MDGS had higher TBARS values on d 0 and 56 of storage $(P=$ 0.04 and $P=0.001$, respectively; Table 6 ) than links from cattle fed CCGF, with treatments not being different on all other days of frozen storage.

Regardless of dietary treatment, the addition of rosemary and green tea extract $(0.13$ and $0.20 \%)$ as an antioxidant was effective at limiting lipid oxidation in refrigerated or frozen storage. The lack of dietary effects when rosemary and green tea extract were included in the statistical analysis for lipid oxidation is likely due to the effectiveness of the antioxidant. Analysis of just cooked beef links with $0 \%$ added rosemary and green tea extract in frozen storage indicated a dietary effect where high supplementation of MDGS during backgrounding yielded greater lipid oxidation than low supplementation on d 9, 12, and 18 of storage. This agrees with the research conducted by Dierks et al. (2017), which determined that supplementation of DDGS during backgrounding resulted in greater lipid oxidation of cooked beef patties in frozen storage, regardless of finishing diet.

\section{IMPLICATIONS}

Backgrounding supplementation had minimal effect on fatty acid composition, but backgrounding supplementation with greater amounts of MDGS did affect lipid oxidation of cooked beef links in refrigerated (d 9, 12, and 18) and frozen (d 168) storage. Finishing diets including
MDGS increased PUFA concentrations, resulted in greater discoloration in raw beef in retail display (d 3, 5, and 6 ), and increased lipid oxidation in cooked beef links in refrigerated (d 9) and frozen (d 0 and 56) storage. However, the addition of antioxidant compounds counteracted any dietary effect of feeding MDGS in cooked beef links in refrigerated and frozen storage. These findings identify the effects of feeding ethanol co-products to cattle on raw and cooked ground beef and demonstrate the effectiveness of added antioxidants in cooked beef products.

\section{ACKNOWLEDGMENTS}

This project was funded in part by the Beef Checkoff through the Nebraska Beef Council. Additional support was provided by the Nebraska Agricultural Experiment Station with Hatch funding (232132) from the USDA National Institute of Food and Agriculture.

\section{LITERATURE CITED}

Ahn, D. U., D. G. Olson, C. Jo, X. Chen, C. Wu, and J. I. Lee. 1998. Effect of muscle type, packaging, and irradiation on lipid oxidation, volatile production, and color in raw pork patties. Meat Sci. 49:27-39.

Ahn, J., I. U. Grün, and A. Mustapha. 2007. Effects of plant extracts on microbial growth, color change, and lipid oxidation in cooked beef. Food Microbiol. 24:7-14.

AOAC. 1990. Fat (crude) or ether extract in meat. Official methods 960.39. Pages 931-932 in Official Methods of Analysis. Assoc. Offic. Anal. Chem., Arlington, VA.

Bremer, V. R. 2010. Distillers grains with solubles for feedlot cattleFinishing performance, lipid metabolism, and ethanol greenhouse gas balance. PhD Diss. Univ. Nebraska-Lincoln, Lincoln.

Buckner, C. D., T. J. Klopfenstein, K. M. Rolfe, W. A. Griffin, M. J. Lamothe, A. K. Watson, J. C. MacDonald, W. H. Schacht, and P. Schroeder. 2013. Ruminally undegradable protein content and digestibility for forages using the mobile bag in situ technique. J. Anim. Sci. 91:2812-2822.

Buege, J. A., and S. D. Aust. 1978. Microsomal lipid peroxidation. Methods Enzymol. 52:302-310.

Buttrey, E. K., F. T. McCollum, K. H. Jenkins, J. M. Patterson, B. E. Clark, M. K. Luebbe, T. E. Lawrence, and J. C. MacDonald. 2012. Use of dried distillers grains throughout a beef production system: Effects on stocker and finishing performance, carcass characteristics, and fatty acid composition of beef. J. Anim. Sci. 90:2381-2393.

Campo, M. M., G. R. Nute, S. I. Hughes, M. Enser, J. D. Wood, and R. I. Richardson. 2006. Flavour perception of oxidation in beef. Meat Sci. 72:303-311.

Chao, M. D. 2015. Impact of wet distillers grains plus solubles and antioxidants on a basic mechanism of beef tenderization. PhD Diss. Univ. Nebraska-Lincoln, Lincoln.

Depenbusch, B. E., C. M. Coleman, J. J. Higgins, and J. S. Drouillard. 2009. Effects of increasing levels of dried corn distillers grains with solubles on growth performance, carcass characteristics, and meat quality of yearling heifers. J. Anim. Sci. 87:2653-2663.

Dierks, N. T., B. D. Cleveland, K. A. Varnold, G. E. Erickson, and G. A. Sullivan. 2017. Effects of feeding wet distillers grains to cattle during different phases of production on lipid oxidation of cooked ground beef patties during storage. Prof. Anim. Sci. 33:54-62. 
Domenech-Perez, K. 2016. Impact of wet distillers grains plus solubles and antioxidants on a basic mechanism of beef tenderization. PhD Diss. Univ. Nebraska-Lincoln, Lincoln.

Faustman, C., Q. Sun, R. Mancini, and S. P. Suman. 2010. Myoglobin and lipid oxidation interactions: Mechanistic bases and control. Meat Sci. 86:86-94.

Folch, J., M. Lees, and G. H. S. Stanley. 1957. A simple method for the isolation and purification of total lipides from animal tissues. J. Biol. Chem. 226:497-509.

Gill, R. K., D. L. VanOverbeke, B. Depenbusch, J. S. Drouillard, and A. DiCostanzo. 2008. Impact of beef cattle diets containing corn or sorghum distillers grains on beef color, fatty acid profiles, and sensory attributes. J. Anim. Sci. 86:923-935.

Greene, B. E., and T. H. Cumuze. 1982. Relationship between TBA numbers and inexperienced panelists' assessments of oxidized flavor in cooked beef. J. Food Sci. 47:52-54.

Gunn, P. J., A. D. Weaver, R. P. Lemenager, D. E. Gerrard, M. C. Claeys, and S. L. Lake. 2009. Effects of dietary fat and crude protein on feedlot performance, carcass characteristics, and meat quality in finishing steers fed differing levels of dried distillers grains with solubles. J. Anim. Sci. 87:2882-2890.

Jenschke, B. E., J. R. Benton, C. R. Calkins, T. P. Carr, K. M. Eskridge, T. J. Klopfenstein, and G. E. Erickson. 2008. Chemical and sensory properties of beef of known source and finished on wet distillers grains diets containing varying types and levels of roughage. J. Anim. Sci. 86:949-959.

Jiang, T., J. R. Busboom, M. L. Nelson, J. O'Fallon, T. P. Ringkob, D. Joos, and K. Piper. 2010. Effect of sampling fat location and cooking on fatty acid composition of beef steaks. Meat Sci. 84:86-92.

Koger, T. J., D. M. Wulf, A. D. Weaver, C. L. Wright, K. E. Tjardes, K. S. Mateo, T. E. Engle, R. J. Maddock, and A. J. Smart. 2010. Influence of feeding various quantities of wet and dry distillers grains to finishing steers on carcass characteristics, meat quality, retail-case life of ground beef, and fatty acid profile of longissimus muscle. J. Anim. Sci. 88:3399-3408.

Liu, Q., M. C. Lanari, and D. M. Schaefer. 1995. A review of dietary vitamin E supplementation for improvement of beef quality. J. Anim. Sci. 73:3131-3140.

Mello, A. S., B. E. Jenschke, L. S. Senaratne, T. P. Carr, G. E. Erickson, and C. R. Calkins. 2012. Effects of feeding modified distillers grains plus solubles on marbling attributes, proximate composition, and fatty acid profile of beef. J. Anim. Sci. 90:4634-4640.

Metcalfe, L. D., A. A. Schmitz, and J. R. Pelka. 1966. Rapid preparation of fatty acid esters from lipids for gas chromatographic analysis. Anal. Chem. 38:514-515.
Min, B., J. C. Cordray, and D. U. Ahn. 2010. Effect of NaCl, myoglobin, $\mathrm{Fe}(\mathrm{ii})$, and $\mathrm{Fe}(\mathrm{iii})$ on lipid oxidation of raw and cooked chicken breast and beef loin. J. Agric. Food Chem. 58:600-605.

Morrison, W. R., and L. M. Smith. 1964. Preparation of fatty acid methyl esters and dimethylacetals from lipids with boron fluoridemethanol. J. Lipid Res. 5:600-608.

Renewable Fuel Association. 2016. Co-products. Accessed Nov. 27, 2016. http://ethanolrfa.org/resources/industry/co-products/ \#1456865649440-ae77f947-734a.

Sato, K., and G. R. Hegarty. 1971. Warmed-over flavor in cooked meats. J. Food Sci. 36:1098-1102.

Schacht, W. H., J. D. Volesky, D. E. Bauer, and M. B. Stephenson. 2011. Grazing Systems for Nebraska Sandhills Rangeland. Univ. Nebraska-Lincoln Extension. EC127. Accessed Dec. 14, 2016. http:// extensionpublications.unl.edu/assets/pdf/ec127.pdf.

Srinivasan, S., Y. L. Xiong, S. P. Blanchard, and W. G. Moody. 1998. Proximate, mineral and fatty acid composition of semimembranosus and cardiac muscles from grass- and grain-fed and zeranol-implanted cattle. Food Chem. 63:543-547.

Sudbeck, K. M., K. A. Varnold, J. C. MacDonald, C. R. Calkins, and G. E. Erickson. 2014. Effects of feeding distillers grains in a yearling beef system on meat quality. Univ. Nebr. Beef Cattle Reports. M99: 111-113. Accessed Nov. 27, 2016. http://beef.unl.edu/ nebeefreport2014.

Tang, S., J. P. Kerry, D. Sheehan, D. J. Buckley, and P. A. Morrissey. 2001. Antioxidative effect of added tea catechins on susceptibility of cooked red meat, poultry and fish patties to lipid oxidation. Food Res. Int. 34:651-657.

Tarladgis, B. G., B. M. Watts, M. T. Younathan, and L. Dugan. 1960. A distillation method for the quantitative determination of malonaldehyde in rancid foods. J. Am. Oil Chem. Soc. 37:44-48.

USDA. 2014. Institutional meat purchasing specifications. Accessed Aug. 15, 2016. https://www.ams.usda.gov/grades-standards/imps.

Van Soest, P. J., J. B. Robertson, and B. A. Lewis. 1991. Methods for dietary fiber, neutral detergent fiber, and non-starch polysaccharides in relation to animal nutrition. J. Dairy Sci. 74:3583-3597.

Vander Pol, K. J., M. K. Luebbe, G. I. Crawford, G. E. Erickson, and T. J. Klopfenstein. 2009. Performance and digestibility characteristics of finishing diets containing distillers grains, composites of corn processing coproducts, or supplemental corn oil. J. Anim. Sci. 87:639-652. 